Pearce, G.W. (1965) Histopathology of voluntary muscle. Postgraduate Medical Journal, 41, 294.

Salmon, S.E. \& Turner, C.E. (1965) McArdle's disease presenting as convulsion and rhabdomyolysis. American Journal of Medicine, 39, 142.

Salter, R.H., Adamson, D.G. \& Pearce, G.W. (1967)
McArdle's syndrome (myophosphorylase deficiency). Quarterly Journal of Medicine, 144, 565.

Schmid, R. \& MAHLER, R. (1959) Chronic progressive myopathy with myoglobinuria: demonstration of a glycogenolytic defect in the muscle. Journal of Clinical Investigation, 38, 2044.

\title{
Acute onset diabetes due to an ACTH secreting oat cell carcinoma of the bronchus
}

\author{
Norman G. SOLER \\ M.D., Ph.D., M.R.C.P.
}

\section{General Hospital, Birmingham, B4 6NH}

\begin{abstract}
Summary
Diabetes of acute onset led to this patient's referral to hospital. Following investigation, it became apparent that the diabetes was only part of the wider clinical picture produced by an ACTH secreting oat cell carcinoma of the bronchus.
\end{abstract}

DiabeTES, which is secondary to other diseases, is quite commonly seen. However, diabetes of acute onset due to ACTH production by an oat cell carcinoma of the bronchus is a distinctly uncommon presentation. Cushing's disease occurs in between $0.5 \%$ and $2 \%$ of bronchial carcinomas (Azzopardi, Freeman \& Poole, 1970; Ross, 1966) and diabetes may be one of the features of its variable clinical effects (Bayliss, 1971). In the present case, clinical evidence of adrenal cortical over-activity appeared before the underlying malignant tumour had been diagnosed and the patient was referred to hospital with a diagnosis of diabetes.

\section{Case report}

A 66-year-old man had an appointment at the diabetic clinic, but due to the urgency of his symptoms, the general practitioner decided to ask for an emergency admission to hospital. His main complaints were thirst and polyuria for the last 7 days and he had heavy glycosuria. There was also a history of increasing shortness of breath for the past 2 years. Although this symptom had been investigated 18 months previously with an X-ray chest and an ECG, a diagnosis had not been reached. He had smoked 20 cigarettes a day all his life and shortness of breath did not alter his habits.

Clinical examination showed an ill, drowsy, dehydrated man with a pigmented facial appearance. He had bilateral ankle oedema, but no finger clubbing or enlarged lymph glands. His pulse was feeble and irregular and his blood pressure was $120 / 60 \mathrm{mmHg}$. There were no murmurs over the praecordium and the breath sounds were normal with no accompaniments. In the abdomen a firm liver was palpable two fingers below the costal margin.

The initial investigations confirmed a diagnosis of diabetes mellitus as his random blood sugar result was $250 \mathrm{mg} / 100 \mathrm{ml}$. Other investigations on admission to hospital were serum $\mathrm{Na}^{+} 144 \mathrm{mEq} / \mathrm{l}$, serum $\mathrm{K}^{+} 2.5 \mathrm{mEq} / 1$, blood urea $40 \mathrm{mg} / 100 \mathrm{ml}$, pH 7.53, $\mathrm{pCO}_{2} 44$, and standard bicarbonate $35 \mathrm{mEq} / \mathrm{l}$. Total proteins $5.3 \mathrm{~g}$, albumin $3.1 \mathrm{~g}$, globulin $2 \cdot 2 \mathrm{~g}$, serum Ca $8.4 \mathrm{mg} / 100 \mathrm{ml}$, alkaline phosphatase 19 units, bilirubin $1.7 \mathrm{mg} / 100 \mathrm{ml}$ and aspartate aminotransferase (SGOT) 160. Repeated electrocardiograms showed supraventricular arrhythmias with varying atrioventricular conduction. A portable $\mathrm{X}$-ray of his chest indicated bilateral hilar gland enlargement.

Within a couple of days, despite a restricted carbohydrate intake and oral hypoglycaemic agents, his blood sugars had risen to between 300 and $400 \mathrm{mg} /$ $100 \mathrm{ml}$ and treatment with insulin became necessary. Although potassium supplements were being given, the serum potassium remained below $2.6 \mathrm{mEq} / 1$ and $24 \mathrm{hr}$ urine collections showed that he was still losing between 90 and $96 \mathrm{mEq}$ of potassium per day. He was, therefore, given an infusion of $\mathbf{2 7 0}$ $\mathrm{mEq}$ of potassium in $0.45 \% \mathrm{~N}$ saline over $36 \mathrm{hr}$ and in this way the serum potassium rose to $4.2 \mathrm{mEq} / \mathrm{l}$. At this stage the ECG reverted to sinus rhythm. Serum cortisol levels were determined on venous bloods 
taken at $\mathbf{9 . 0 0}$ am and at midnight on three consecutive days and all the results were between 70 and 80 $\mu \mathrm{g} / 100 \mathrm{ml}$ without any diurnal variation.

Tomograms of the hilar regions of the lungs confirmed the bilateral hilar lymphadenopathy and showed a rounded shadow at the upper part of the right hilum. A liver biopsy indicated infiltration by secondary carcinoma which had the appearance of an oat cell carcinoma of the bronchus. Arrangements were made to start radiotherapy, but following the first treatment his respiratory condition deteriorated and he died within the next $24 \mathrm{hr}$. At necropsy the diagnosis of an oat cell carcinoma of the bronchus was confirmed, the tumour arising within $1 \mathrm{~cm}$ of the origin of the right upper lobe bronchus. The hilar lymph nodes showed extensive replacement by secondary carcinoma. Numerous secondary deposits were present in the liver and in the bone marrow of the lumbar spine. The immediate cause of death was a pulmonary embolus which led to infarction of the right lower lobe.

\section{Comment}

This patient had an oat cell carcinoma of the bronchus with widespread metastases. In life his pigmented appearance and generalized weakness together with the biochemical findings of hypokalaemia and metabolic alkalosis suggested nonendocrine production of adrenocorticotrophin. The high serum cortisol levels without any diurnal variation were also in favour of this diagnosis and were in the same range recorded by other workers studying this condition (Friedman, MarshallJones \& Ross, 1966; O'Riordan et al., 1966). It is also likely that the diabetes was a result of the adrenocortical hyperactivity, especially as there was no family history of diabetes in this case. The patient had received diuretic drugs (bendrofluazide) with potassium supplements intermittently in the past, but not in recent weeks, so that it is unlikely that their diabetogenic effect was responsible for his acute diabetic symptoms. On the other hand, hypokalaemia, whatever its cause, interferes with insulin secretion and impairs insulin activity on peripheral tissues (Seltzer, 1970).

Management proved difficult during the short stay in hospital preceding the death of this patient. Initially, problems were encountered in controlling the diabetes and correcting his hypokalaemia. The alarming cardiac arrhythmias only resolved when normokalaemia had been re-established. As usual in these cases (Friedman et al., 1966), the serum potassium was again falling steadily despite the administration of potassium chloride and aldactone when his respiratory condition deteriorated 2 weeks after admission to hospital and he died of a massive pulmonary embolus.

At least two standard textbooks on diabetes (Malins, 1968; Oakley, Pyke \& Taylor, 1968) fail to mention adrenocorticotrophin produced by nonendocrine tumours as a possible cause of diabetes, though they mention classical Cushing's disease. Since of all the hormones produced by non-endocrine tumours adrenocorticotrophin is the most common (Bayliss, 1971) there is a case for remembering this possible, though uncommon, cause of diabetes. A wide variety of neoplasms may be responsible, but bronchial oat cell carcinoma is by far the commonest. The finding of adrenocortical hyperactivity in patients with neoplasms carries an extremely poor prognosis for life (Friedman et al., 1966). Glycosuria and hyperglycaemia may only be incidental findings, but other cases have severe diabetes (Azzopardi, 1968; Bayliss, 1971). In the patient just described the diabetes was severe enough to bring him under medical attention and the diagnosis of malignancy was only arrived at later.

\section{Acknowledgment}

I should like to thank Professor J. M. Malins for allowing me to publish this case report.

\section{References}

Azzopardi, J.G. (1968) In: Fourth Symposium of Advanced Medicine (Ed. by O. Wrong). Pitman, London.

Azzopardi, J.G., Freeman, E. \& Poole, G. (1970) Endocrine and metabolic disorders in bronchial carcinoma. British Medical Journal, 4, 528.

BAYliss, R.I.S. (1971) In: Progress in Clinical Medicine (Ed. by R. Daley and H. Miller), 6th edn, p. 208. ChurchillLivingstone, London.

Friedman, M., Marshall-Jones, P. \& Ross, E.J. (1966) Cushing's syndrome: Adrenocortical hyperactivity secondary to neoplasms arising outside the pituitary adrenal system. Quarterly Journal of Medicine, 35, 193.

Malins, J.M. (1968) Clinical Diabetes Mellitus, p. 289. Eyre and Spottiswoode, London.

OAKley, W.G., Pyke, D.A. \& TAYloR, K.W. (1968) Clinical Diabetes, p. 154. Blackwell Scientific Publications, Oxford.

O'RioRdan, J.L.H., Blanshard, G.P., MaXhaM, A. \& NABARRO, J.D.N. (1966) Corticotrophin-secreting carcinomas. Quarterly Journal of Medicine, 35, 137.

Rกss, E. J. (1966) Proceedings of the Royal Society of Medicine, $59,335$.

Seltzer, H.S. (1970) In: Diabetes Mellitus: Theory and Practice (Ed. by M. Ellenberg and H. Rifkin), p. 458. McGraw-Hill, New York. 